\title{
The Effect of Drying and Storage on the Quality of Shallot (Allium Cepa L. Aggregatum Group) Bulbs
}

\author{
Rohimah Handayani Sri Lestari ${ }^{1,2 *}$, Endang Sulistyaningsih ${ }^{2}$, Aziz Purwantoro ${ }^{2}$ \\ ${ }^{1}$ Assessment Institute for Agricultural Technology of Papua \\ Jln. Yahim No. 49 Sentani, Sentani, Jayapura, Papua, 99352 \\ ${ }^{2}$ Department of Agronomy, Faculty of Agriculture Universitas Gadjah Mada \\ Jln. Flora no. 1, Bulaksumur, Sleman, Yogyakarta 55281, Indonesia \\ *Corresponding email: endangsih@ugm.ac.id
}

\begin{abstract}
Post-harvest handling of shallot such as drying bulbs can affect its quality during and after storage. The objective of this study was to determine the impact of drying and storage treatment on the quality of shallot bulbs during 12 weeks of storage. The study had been carried out in Samiran sub-village, Parangtritis village, Bantul regency, Special Region of Yogyakarta and Crop Science Laboratory of the Faculty of Agriculture, Universitas Gadjah Mada, from June to November 2016. The study was arranged in factorial randomized complete block design (RCBD) and consisted of two factors. The first factor was the drying treatments that the bulbs were dried on the field and on woven bamboo nets factor both plastic covered and uncovered. The second was the storage treatments that the bulbs were stored in the farmer's warehouse $\left(31.03^{\circ} \mathrm{C} \pm 0.04\right.$ and $\mathrm{RH}$ of $\left.60.50 \% \pm 0.28\right)$, in air-conditioned room $\left(22.40^{\circ} \mathrm{C} \pm 0.02\right.$ and $\mathrm{RH}$ of $61.60 \% \pm 0.09)$, and at room temperature $\left(30.47^{\circ} \mathrm{C} \pm 0.03\right.$ and $\mathrm{RH}$ of $\left.60.50 \% \pm 0.12\right)$. Each treatment combination was replicated three times as blocks. The results showed that water content of all treatments were changing followed by fluctuating of the total soluble solid during the storage period while bulb firmness tended to decrease. Bulbs which were stored in air-conditioned rooms showed the highest percentage of sprouted bulbs, vigor index and germination rate than other treatments. Meanwhile, drying treatment did not give significant effect.
\end{abstract}

Keywords: Seed, shallot, bulb, drying, storage, quality

\section{INTRODUCTION}

The quality of seed is determined based on drying and storage techniques in post-harvest handling. According to Mitra et al. (2012), drying shallot bulb is aimed to reduce the moisture content for preventing any microorganism causing disease from surviving and reproducing. Hall (1980) states that drying as a part of post-harvest handling is required in order to prevent bulbs from any deterioration during the storage. Dried onion is indicated by the appearance of neck shrinkage in the tubers, the drying of outer shell of the tubers and the rustling sound when rubbed against each other (Musaddad and Sinaga, 1995).

The conventional cultural practice of drying shallot bulb applied by the farmers is using direct sunlight on the embankment of their field in 7 to 10 days after harvesting or when all leaves have dried up. It has some negative effects, such as lots of scattered bulbs, scorched bulbs as indicated by changes in shallot skin color, flaccidity, and excessive moisture loss causing much weight loss (Asgar et al., 1992). On one side a large open space for drying is needed, but on the other side we have to think about the emergence of infectious diseases as a result of harvesting at rainy season. The infection is due to drying further imperfections that consequently degrade the quality and shorten the durability in the storing process.

Alternative method of bulbs drying is on woven bamboo nets supported with bamboo sticks to prevent the bulbs from direct contact with the ground. By using this method, an evenly dryness level can be obtained due to the presence of well-ventilated nets that results in more efficient drying period and minimizes the possibility of dirt contamination. This 
method is also expected to prevent the plant from disease because it is actually a manipulation of heating treatment to the bulbs from the development of disease on the field. Physical treatment of seed by using heat to control the dispersion of seed-borne disease has been widely used (Primasari, 2016). According to Raka et al. (2012), the heat treatment on seeds is able to control most seed-borne diseases as effectively as chemical treatment, except for diseases located far inside the seed.

After the drying process, the next step is storing the seed in a specific room where temperature and humidity are set to prevent bulb deterioration. Storage temperature and relative humidity are related to sprouting, rooting, and physiological weight loss and storage periods (Nega et al., 2015). Purwanti (2004) notes that storage room is used to retain seed viability during the storage. Seed storage is aimed to obtain high-quality seeds until they are used as planting material (Yudono, 2012). Generally, the seeds are stored traditionally in a room set at a temperature of $25-30^{\circ} \mathrm{C}$ with relative humidity of $70-80 \%$, which potentially reduces the weight up to $25 \%$ after 2 months of storage (Komar et al., 2001). The weight loss is maintained to be as low as $10-17 \%$ by controlling the external factors, such as temperature and humidity. According to Purwanto et al. (2012), setting the storage room at low temperature is able to inhibit the weight loss process, retain moisture content, and sustain seed quality, as well as prolong its shelf life.

Based on the above mentioned, a proper postharvest handling for both the drying and storage aspects is urgently required in order to have highly vigorous shallot bulbs when grown. The objective of this study was to identify the quality of the shallot bulbs during the 12 weeks of storage as the impact of the drying and storage treatments.

\section{MATERIALS AND METHODS}

The quality of seed is determined based on drying and storage techniques in post-harvest handling. According to Mitra et al. (2012), drying shallot bulb is aimed to reduce the moisture content for preventing any microorganism causing disease from surviving and reproducing. Hall (1980) states that drying as a part of post-harvest handling is required in order to prevent bulbs from any deterioration during the storage. Dried onion is indicated by the appearance of neck shrinkage in the tubers, the drying of outer shell of the tubers and the rustling sound when rubbed against each other (Musaddad and Sinaga, 1995).
The conventional cultural practice of drying shallot bulb applied by the farmers is using direct sunlight on the embankment of their field in 7 to 10 days after harvesting or when all leaves have dried up. It has some negative effects, such as lots of scattered bulbs, scorched bulbs as indicated by changes in shallot skin color, flaccidity, and excessive moisture loss causing much weight loss (Asgar et al., 1992). On one side a large open space for drying is needed, but on the other side we have to think about the emergence of infectious diseases as a result of harvesting at rainy season. The infection is due to drying further imperfections that consequently degrade the quality and shorten the durability in the storing process.

Alternative method of bulbs drying is on woven bamboo nets supported with bamboo sticks to prevent the bulbs from direct contact with the ground. By using this method, an evenly dryness level can be obtained due to the presence of well-ventilated nets that results in more efficient drying period and minimizes the possibility of dirt contamination. This method is also expected to prevent the plant from disease because it is actually a manipulation of heating treatment to the bulbs from the development of disease on the field. Physical treatment of seed by using heat to control the dispersion of seed-borne disease has been widely used (Primasari, 2016). According to Raka et al. (2012), the heat treatment on seeds is able to control most seed-borne diseases as effectively as chemical treatment, except for diseases located far inside the seed.

After the drying process, the next step is storing the seed in a specific room where temperature and humidity are set to prevent bulb deterioration. Storage temperature and relative humidity are related to sprouting, rooting, and physiological weight loss and storage periods (Nega et al., 2015). Purwanti (2004) notes that storage room is used to retain seed viability during the storage. Seed storage is aimed to obtain high-quality seeds until they are used as planting material (Yudono, 2012). Generally, the seeds are stored traditionally in a room set at a temperature of $25-30^{\circ} \mathrm{C}$ with relative humidity of $70-80 \%$, which potentially reduces the weight up to $25 \%$ after 2 months of storage (Komar et al., 2001). The weight loss is maintained to be as low as $10-17 \%$ by controlling the external factors, such as temperature and humidity. According to Purwanto et al. (2012), setting the storage room at low temperature is able to inhibit the weight loss process, retain moisture content, and sustain seed quality, as well as prolong its shelf life.

Based on the above mentioned, a proper postharvest 
handling for both the drying and storage aspects is urgently required in order to have highly vigorous shallot bulbs when grown. The objective of this study was to identify the quality of the shallot bulbs during the 12 weeks of storage as the impact of the drying and storage treatments. The observation variables after drying were:

(1). Temperature and humidity of the environment of drying; (2). Moisture content (\%), measured in oven method (AOAC, 1995):

$$
\text { Moisture content }=\frac{\text { gross weight }- \text { dry weight }}{\text { gross weight }} \times 100 \%
$$

(3). Weight loss, measured by weighing the initial and final weight of bulbs under the following formula:

Weight loss $=\frac{\text { weight of bulbs before drying-weight of bulbs after drying }}{\text { weight of bulbs before drying }}$

Before the seeds were stored, the initial condition of the seeds, such as water content, total soluble solids and bulb firmness, was measured. The storage was 12 weeks with monitoring carried out once in two weeks; except for the final weight-loss variable, the damaged bulbs, and the sprouting bulbs, which were examined after the end of the storing. The observation variables during the storage were:

(1). Moisture content (\%); the formula was similar to the moisture content when in the drying process; (2). The bulb firmness measured by a pneumatic tool "Barreiss Prufgeratebau GmbH type BS 61 II / BS 61 II OO 'series 2553". The measurement was done by placing the bulbs on the tool pads and pressing them until the needle touched the skin surface of the bulbs. The numbers shown on the monitor indicated the firmness level of the bulb measured. The fruit firmness was expressed in Newton's unit; (3). Total soluble solids (TSS), measured by the hand-held refractometer "ATAGO' A-01-37 in scale of 0-32\% Brix. The TSS measurement was done by refining the shallot bulbs and squeezing them to remove the essence, which was dripped on the refractometer prism and then covered. The TSS measurement result was directly read by the numbers listed on the refractometer scale; (4). Damaged bulbs (\%), measured by comparing the number of damaged bulbs, including rotten, porous (empty) and rooted seeds with the number of bulbs stored;

$$
\text { Damaged bulbs }=\frac{\text { total of damaged bulbs }}{\text { total of bulbs stored }} \times 100 \%
$$

(5). Sprouting bulbs (\%), measured by comparing the number of sprouting bulbs with the number of bulbs stored;

Sprouting bulbs $=\frac{\text { total of sprouting bulbs }}{\text { total of bulbs stored }} \times 100 \%$

(6). The final weight loss (\%), measured by weighing the initial and final weight of the bulbs under the following formula.

Final weight loss $=\frac{\text { weight of bulbs before storage-weight of bulbs after storage }}{\text { weight of bulbs before storage }} \times 100 \%$

After 12 weeks of storage, the viability and vigorousness of shallot seed bulbs were tested in 14 days. The test included:

(1). Germination

$$
\mathrm{G}=\frac{\text { the germinating seeds until day } 14}{\text { the bulb planted }} \times 100 \%
$$

(2). Vigor Index

$$
\mathrm{VI}=\frac{\mathrm{G} 1}{\mathrm{D} 1}+\frac{\mathrm{G} 2}{\mathrm{D} 2}+\frac{\mathrm{G} 3}{\mathrm{D} 3}+\ldots+\frac{\mathrm{Gn}}{\mathrm{Dn}}
$$

Description:

$\mathrm{VI}=$ Vigor index; $\mathrm{G}=$ number of bulbs germinating on certain days; $\mathrm{D}=$ time corresponding to $\mathrm{G} ; \mathrm{N}=$ the number of days in the final calculation

(3). Germination speed

$$
G S=\sum_{i=0}^{i=n} \% \text { Kn/ etmal }
$$

The data was analyzed using analysis of variance (ANOVA). When significant effect was shown, it was further tested by the Duncan's Multiple Range Test (DMRT) at $\alpha=0.05$.

\section{RESULTS AND DISCUSSION}

\section{Observation during the drying period}

Temperature and air humidity are two key factors contributing to the loss of water vapor on seeds during drying. The average values of temperature and humidity are presented in Table 1.

As seen in Table 1, bulbs drying on the field showed the highest temperature of $41.9 \mathrm{oC}$ and the lowest relative humidity $(56.3 \%)$, whereas bulbs drying on woven bamboo nets which were not covered with plastic showed the lowest temperature of $37.71^{\circ} \mathrm{C}$ and relative humidity of $63.3 \%$.

The higher temperature during the drying process on the field caused the greater weight loss (Table 2). Such high temperature on field caused the moisture content to be easily evaporated and further resulted in lower water content than other treatments 
Table 1. Temperature (0C) and relative humidity (\%) in the drying process.

\begin{tabular}{lcc}
\hline Drying methods & Temperature $\left({ }^{\circ} \mathrm{C}\right)$ & Relative Humidity $(\%)$ \\
\hline On field & $41.9 \pm 0.55$ & $56.3 \pm 1.70$ \\
On woven bamboo nets covered with plastic & $40.8 \pm 0.64$ & $64.6 \pm 1.39$ \\
On woven bamboo nets uncovered with plastic & $37.7 \pm 0.46$ & $63.3 \pm 1.31$ \\
\hline
\end{tabular}

Table 2. Weight loss (\%) and moisture content (\%) of shallot bulbs after drying.

\begin{tabular}{lcc}
\hline Drying methods & Weight loss (\%) & Moisture content (\%) \\
\hline On field & 22.18 & 83.08 \\
On woven bamboo nets covered with plastic & 20.10 & 84.31 \\
On woven bamboo nets unovered with plastic & 21.82 & 84.87 \\
\hline
\end{tabular}

Table 3. Moisture content (\%), bulb firmness (N), and total soluble solid (TSS) ( ${ }^{\circ}$ Brix) before storage

\begin{tabular}{lccc}
\hline Treatments & $\begin{array}{c}\text { Moisture } \\
\text { content }(\%)\end{array}$ & $\begin{array}{c}\text { Bulb Firmness } \\
(\mathrm{N})\end{array}$ & $\begin{array}{c}\text { TSS } \\
\left({ }^{\circ} \text { Brix }\right)\end{array}$ \\
\hline Drying methods & & & \\
On the field & $83.08 \mathrm{a}$ & $98.86 \mathrm{a}$ & $15.88 \mathrm{a}$ \\
On woven bamboo nets covered with plastic & $84.31 \mathrm{~b}$ & $98.77 \mathrm{a}$ & $15.59 \mathrm{a}$ \\
On woven bamboo nets uncovered with plastic & $84.87 \mathrm{c}$ & $98.77 \mathrm{a}$ & $15.55 \mathrm{a}$ \\
Storage methods & & & \\
Farmer's warehouse & $83.70 \mathrm{p}$ & $98.75 \mathrm{p}$ & $15.40 \mathrm{p}$ \\
Air-conditioned room & $84.21 \mathrm{p}$ & $98.87 \mathrm{p}$ & $15.83 \mathrm{p}$ \\
Room temperature & $84.35 \mathrm{p}$ & $98.77 \mathrm{p}$ & $15.50 \mathrm{p}$ \\
\hline Interaction & - & - & - \\
\hline C.V $(\%)$ & 1.66 & 0.76 & 6.73
\end{tabular}

Note: The numbers in the columns followed by the same letters are not significantly different according to Duncan Multiple with $\alpha=5 \%$; (-): There is no interaction between factors being tested.

(Table 2). In line with Astuti's statement (2008), the higher the drying temperature, the lower the water content would be, due to more opened material pore and loosen air density facilitating the water to evaporate from the material.

\section{Observation during storage period}

Prior to 12 weeks of storage, the initial quality of shallot including bulb moisture content, bulb firmness, and total soluble solid (TSS) was measured (Table 3).Based on the data, there was a significant difference on the bulb moisture content due to the curing method, where drying bulbs on the field showed the lowest moisture content compare to other drying methods. Drying bulbs on woven bamboo nets which were not covered with plastic had the highest moisture content. The low level of moisture content from drying on field was associated with the higher temperatures during the drying (Table 3 ).

Moisture content was one of the important factors considered during the storage because it could potentially affect the food quality (Mardiana, 2016). Changes in moisture content of shallot bulbs for 12 weeks of storage are presented on Figure 1.

Figure 1 shows the changes of water content in the shallot bulb seed with drying treatment and 12 weeks of storage. The drying treatments indicate the fluctuating changes of water content towards the end of observation (Figure 1.a). From the beginning to the end of the storage, the decrease of water content in the drying treatment with plastic-covered bamboo woven and the drying treatment on field were $1.57 \%$ and $0.37 \%$, respectively. Decreasing on drying treatment on the field might have been affected by higher temperatures during the process which caused hardening on the skin of the shallot and providing protection against shrinkage of water contained in the bulbs. The result was supported by Djali (2013) and Hervelly (2005) whom stated that drying will cause the shallot outer skin to dry up which then limits the excessive expenditure of water from the bulbs during storage thus the decrease in water 

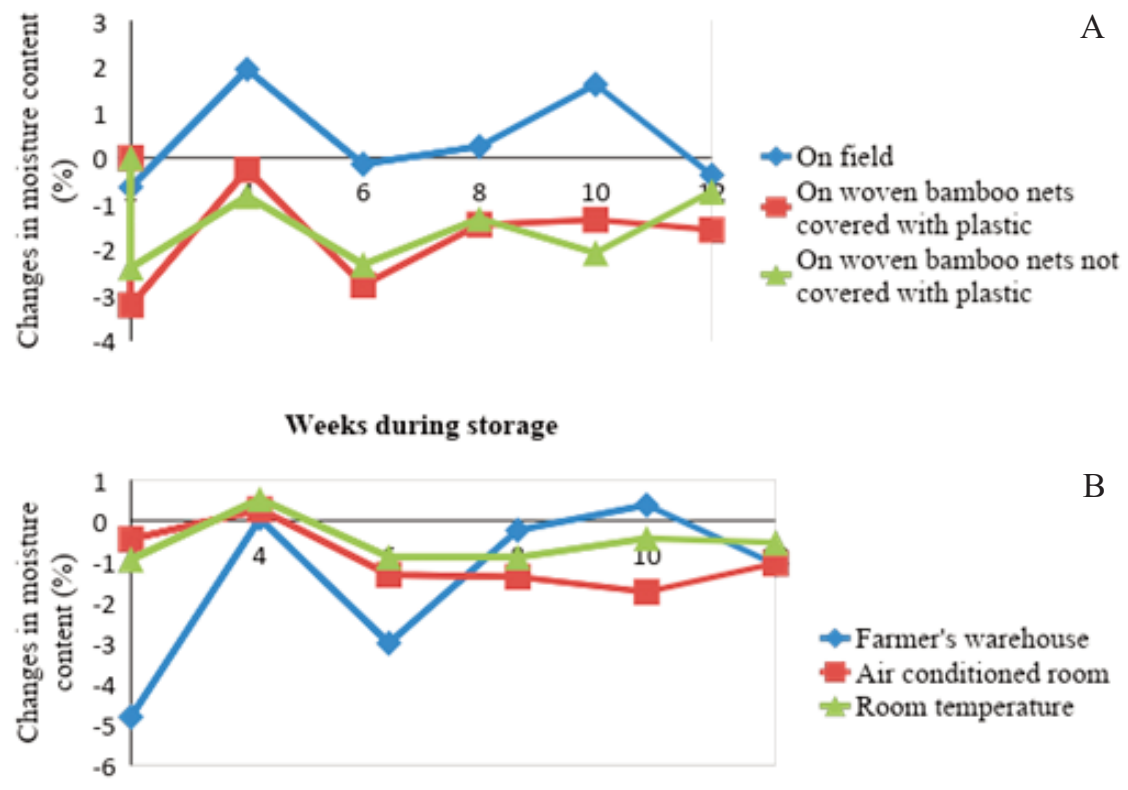

Weeks during storage

Figure 1. Changes in moisture content of shallot bulbs during 12 weeks of storage. A: Drying treatment; B: Storage treatment

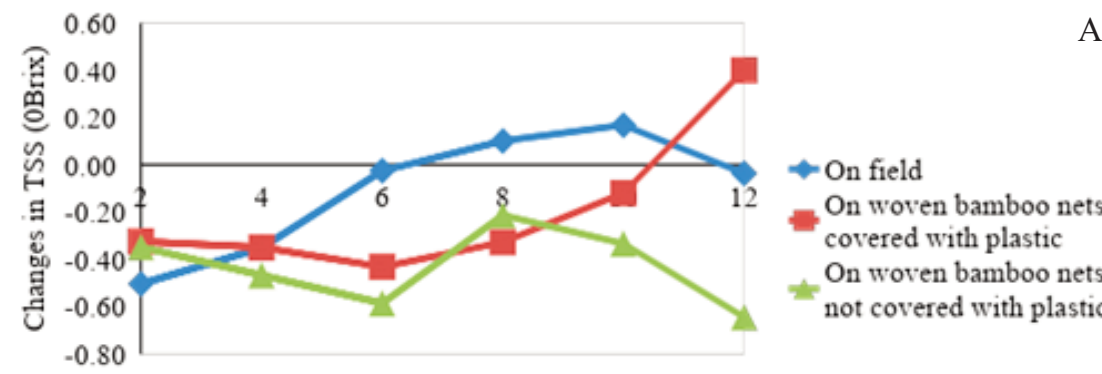

A

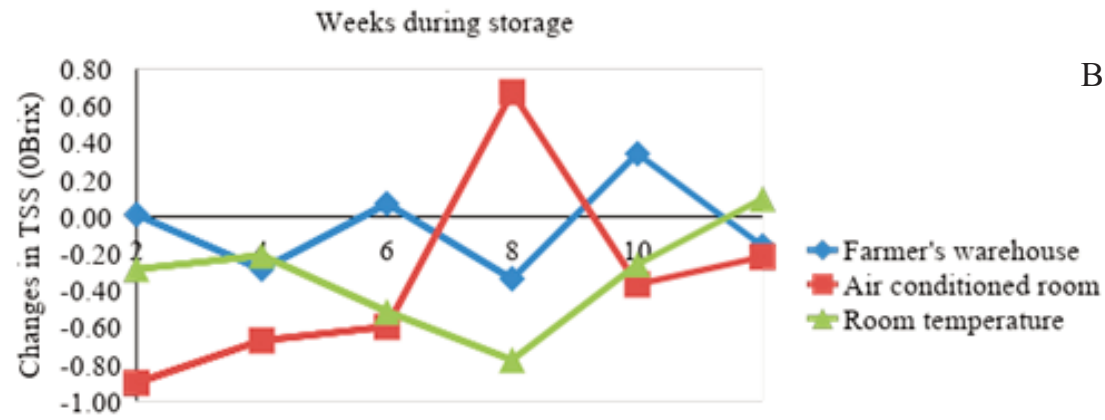

Weeks during storage

Figure 2. Changes in TSS content during 12 weeks of storage. A: Drying treatment; B: Storage treatment

content takes place more slowly.

Although water content decreased during the drying storage, it was still within the safe limit for the seed quality. In line with the study conducted by Djali (2013); Mardiana (2016); If'all and Idris (2016), 80 $85 \%$ of water content would result in good quality of bulbs.

Not so much different results were obtained from the storage treatment as water content in the bulb also fluctuated. From the beginning to the end of the storage, the decrease of water content of the shallot bulb from the storage treatment in farmer's warehouse was $1.08 \%$. This was not much different from that in air-conditioned room $(1.05 \%)$. The lowest decrease of water with storage treatment in a room temperature was $0.54 \%$. Similar to drying treatment, the decrease of water content with the storage treatment was also within the safe limit which is able to sustain shallot seed quality. 
Fluctuating changes referred more to its response to the environmental conditions during the storage. This was due to its hygroscopic characteristics, in which the moisture content of the bulbs is always adjusted to the water content. In accordance with Mutia's statement (2014), seeds stored at temperature of $26-320 \mathrm{C}$ and $52-88 \%$ of humidity will easily absorb and evaporate water from the bulbs and cause changes in moisture content. Further, Priyantono et al. (2013) detailed that the unstable condition and temperature of the storage environment will cause the shallot to easily absorb and evaporate water from the bulbs. However, if the water content remains low within the maximum limit, the seed will be able to maintain its quality due to the fact that the viability and vigorousness remain fit (Iffal and Idris, 2016).

Total Soluble Solids (TSS) were defined as all existing solids and water-soluble solids in the bulbs including reduced sugars, sucrose, organic acids and water-soluble vitamins (Asgar and Marpaung, 1998). Changes in TSS content during 12 weeks of storage are presented in Figure 2.

The changes of TSS at the end of the drying treatment with plastic-covered bamboo woven tended to increase $\left(0.39^{\circ} \mathrm{Brix}\right)$, which was different from two other treatments. The high content of TSS in the treatment was related to the moisture content contained in the bulbs. According to Djali (2013) and Sinaga \& Nurhatuti (1991), the change of TSS is related to the pattern of changes in moisture content that leads to decrease in water content resulting in an increase of TSS content. The result was clearly showed by the bulbs with drying treatment using plastic-covered woven which had the highest water content reduction $(1.57 \%)$ so the TSS content will increase. Drying on field treatment and plastic uncovered treatment tended to experience decrease of TSS, each of which by 0.04 and $0.64{ }^{\circ}$ Brix (Figure 2A), respectively. The tendency of increasing TSS content from plastic-covered woven bamboo treatment began from week 6 . Meanwhile, the tendency of TSS decrease from on the field and plasticuncovered woven bamboo treatments began from week 10.

Slightly different result was shown from the storage treatment (Figure 2B). TSS with storage treatment in farmers' warehouse fluctuated form the beginning towards the end of the storage process. Different from room-temperature treatment storage, within week 4 to 8 , TSS tended to decrease and began to increase toward the end of the storage. With storage treatment in air-conditioned room, TSS tended to increase up to week 8 and decrease when entering week 10 but the increase again to the end of the storage. The highest TSS decrease from the beginning to the end of storage occurred from treatment in airconditioned room which was $0.22^{\circ} \mathrm{Brix}$, while the lowest water content decrease occurred from storage treatment in farmer's warehouse which was $0.16^{\circ}$ Brix.
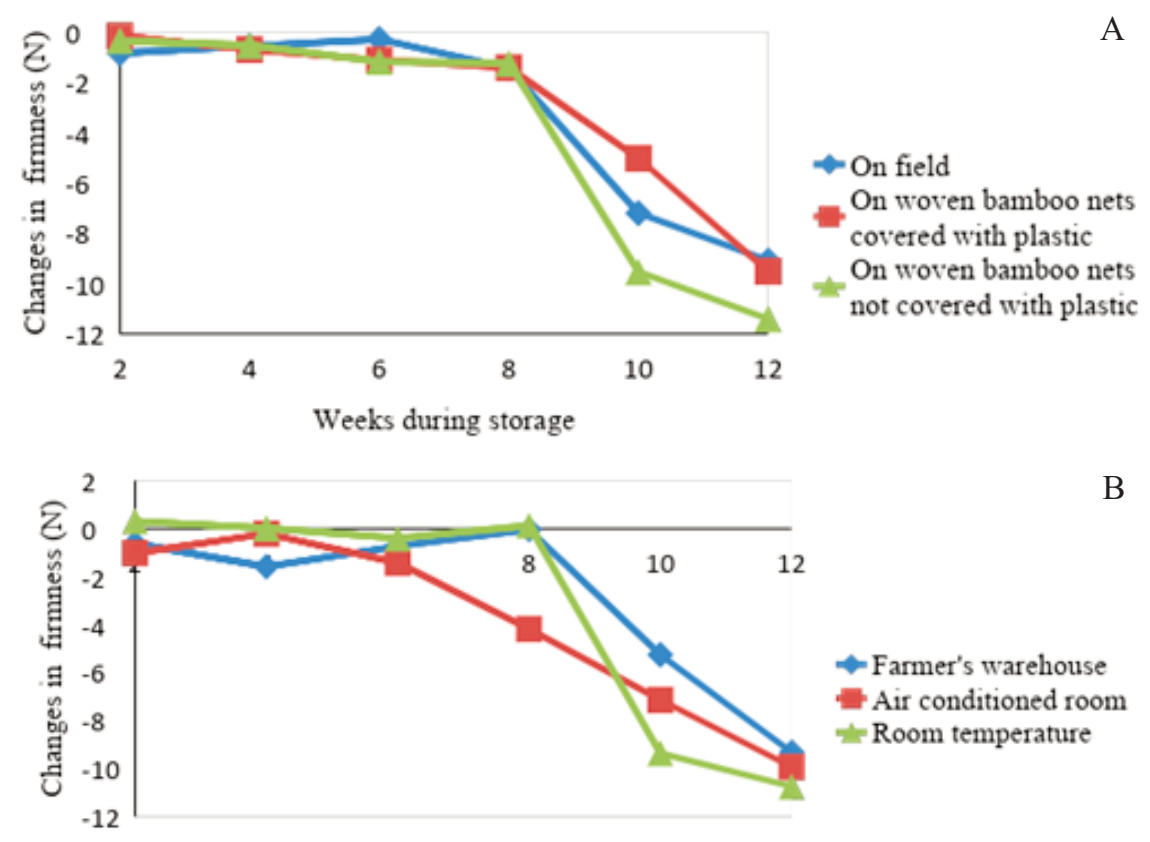

Weeks during storage

Figure 3. Changes in bulb firmness during the 12 weeks of storage. A: Drying treatment; B: Storage treatment 
Table 4. Final weight loss (\%) of shallot bulbs after 3 months of storage

\begin{tabular}{lcccc}
\hline \multirow{2}{*}{ Drying methods } & \multicolumn{3}{c}{ Storage methods } & Average \\
\cline { 2 - 4 } & $\begin{array}{c}\text { Farmer's } \\
\text { warehouse }\end{array}$ & $\begin{array}{c}\text { Air-conditioned } \\
\text { room }\end{array}$ & $\begin{array}{c}\text { Room } \\
\text { temperature }\end{array}$ & $12.17 \mathrm{a}$ \\
\hline On the field & 8.41 & 15.79 & 12.31 & $12.94 \mathrm{a}$ \\
On woven bamboo nets covered with plastic & 12.12 & 14.91 & 11.77 & $13.60 \mathrm{a}$ \\
On woven bamboo nets uncovered with plastic & 10.82 & 16.60 & 13.39 & 12.90 \\
\hline Average & $10.45 \mathrm{q}$ & $15.77 \mathrm{p}$ & $12.49 \mathrm{q}$ & \\
\hline C.V $(\%)$ & 16.86 & & & \\
\hline
\end{tabular}

Note: The numbers in the columns followed by the same letters are not significantly different according to Duncan Multiple with $\alpha$ $=5 \%$; (-): There is no interaction between factors being tested.

Table 5. Percentage of sprouting bulbs (\%) after 3 months of storage

\begin{tabular}{lcccc}
\hline \multirow{2}{*}{ Drying methods } & \multicolumn{3}{c}{ Storage methods } & Average \\
\cline { 2 - 4 } & $\begin{array}{c}\text { Farmer's } \\
\text { warehouse }\end{array}$ & $\begin{array}{c}\text { Air-conditioned } \\
\text { room }\end{array}$ & $\begin{array}{c}\text { Room } \\
\text { temperature }\end{array}$ & $0.99 \mathrm{a}$ \\
\hline On the field & 0.00 & 2.99 & 0.00 & $1.47 \mathrm{a}$ \\
On woven bamboo nets covered with plastic & 0.00 & 4.41 & 0.00 & $0.87 \mathrm{a}$ \\
On woven bamboo nets uncovered with plastic & 0.00 & 2.60 & 0.00 & 1.11 \\
\hline Average & 0.00 & $3.34 \mathrm{p}$ & 0.00 & \\
\hline
\end{tabular}

Note: The numbers in the columns followed by the same letters are not significantly different according to Duncan Multiple with $\alpha$ $=5 \%$; (-): There is no interaction between factors being tested: $*=$ Data was transformed with a $\sqrt{ }(\mathrm{x}+1)$

Different from the water content and TSS changes, the bulb firmness from all treatments experienced decrease at the end of 12 weeks of storage (Figure 3A and 3B). It was indicated that during the storage process, all treatments were not able to prevent changes in bulb firmness. In line with the statement of Nugraha et al. (2009), generally the firmness decreases during the storage process. The low level of firmness indicated softening shallot texture. It might occur due to changes in the composition of the cell wall belonging to one of the softening mechanisms commonly found in fruit ripening (Tucker et al., 1993). Along with the opinion of Heatherbell et al. (1982) and Pantastico (1986), during the ripening process, fruit changes its pectin content and the enzyme activity softens the fruit. The degree of firmness depends on the outer shell thickness, the total solid and the starch content of a material (Pangidoan et al., 2014; Pantastico, 1986).

Weight loss is a quality parameter to represent the bulb freshness. During the storage, shallot bulbs lost the weight due to vaporization, decay, and damage. Pantastico (1993) noted that weight loss was mostly affected by respiration and transpiration. As shown in Table 4, the curing method showed insignificant effect among all treatments with the significant effect was found on the storage method. Bulbs stored in the warehouse showed the lowest weight loss although they were insignificantly different in compare to the ones stored at room temperature. This indicated that the treatment was able to suppress the weight loss until the end of storage, while storage treatment in the air-conditioned room was not able to suppress the weight loss due to the high rate of average damage and the number of sprouted bulbs. The data showed that the number of damaged bulbs and the highest sprouted bulbs occurred were affected by airconditioned room storage (Tables 5 and 6). Thus, the weight loss value occurred together with the increase of damage value. In line with the statement of Maemunah (2010), the increase of weight loss was due to the large number of damaged, rooted, and decayed bulbs during storage.

The number of sprouted bulbs was only affected by the storage method (Table 5). Bulbs stored in the air-conditioned room showed larger number of sprouted bulbs than those from other treatments. It was suspected that such larger number of shoots in $\mathrm{AC}$ room storage was due to the $\mathrm{AC}$ temperature that could spur the shallot bulbs. According to Maya (2012), shallot bulbs at 200C temperature showed larger number of sprouted bulbs than those in 100 ${ }^{\circ} \mathrm{C}$ temperature. This indicated that $20-22{ }^{\circ} \mathrm{C}$ temperature storage accelerated the dormancy breakage of the shallot bulbs that were ready to grow. According to Mardiana et al. (2016), the occurrence 
Table 6. Percentage of damaged bulbs (\%) after 3 months of storage.

\begin{tabular}{lcccc}
\hline \multirow{2}{*}{ Drying methods } & \multicolumn{3}{c}{ Storage methods } & Average \\
\cline { 2 - 4 } & $\begin{array}{c}\text { Farmer's } \\
\text { warehouse }\end{array}$ & $\begin{array}{c}\text { Air-conditioned } \\
\text { room }\end{array}$ & $\begin{array}{c}\text { Room } \\
\text { temperature }\end{array}$ & $3.29 \mathrm{a}$ \\
\hline On the field & 1.53 & 6.10 & 2.24 & $4.31 \mathrm{a}$ \\
On woven bamboo nets covered with plastic & 4.06 & 5.75 & 3.11 & $4.44 \mathrm{a}$ \\
On woven bamboo nets uncovered with plastic & 4.12 & 5.32 & $3.08 \mathrm{p}$ & 4.01 \\
\hline Average & $3.24 \mathrm{p}$ & $5.72 \mathrm{p}$ & & \\
\hline C.V $(\%)$ & 22.47 & & & \\
\hline
\end{tabular}

Note: The numbers in the columns followed by the same letters are not significantly different according to Duncan Multiple with $\alpha$ $=5 \% ;(-)$ : There is no interaction between factors being tested: *= Data was transformed with a $\sqrt{ }(x+1)$

Table 7. Vigor index of shallot bulbs after 3 months of storage

\begin{tabular}{lcccc}
\hline \multirow{2}{*}{ Drying methods } & \multicolumn{3}{c}{ Storage methods } & Average \\
\cline { 2 - 4 } & $\begin{array}{c}\text { Farmer's } \\
\text { warehouse }\end{array}$ & $\begin{array}{c}\text { Air-conditioned } \\
\text { room }\end{array}$ & $\begin{array}{c}\text { Room } \\
\text { temperature }\end{array}$ & $4.35 \mathrm{a}$ \\
\hline On the field & 4.13 & 4.87 & 4.06 & $4.54 \mathrm{a}$ \\
On woven bamboo nets covered with plastic & 4.06 & 5.51 & 4.06 & $4.52 \mathrm{a}$ \\
On woven bamboo nets uncovered with plastic & 4.10 & 5.25 & 4.21 & $4.47(-)$ \\
\hline Average & $4.10 \mathrm{q}$ & $5.21 \mathrm{p}$ & $4.11 \mathrm{q}$ & \\
\hline C.V (\%) & 9.03 & & \\
\hline Note: The means in one column followed by the same letter were not significantly different according to DMRT $(\alpha$ 5\%); (-): There \\
$\quad$ is no interaction between factors being tested
\end{tabular}

Table 8. Germination rate (\%/etmal) of shallot bulbs after 3 months of storage

\begin{tabular}{lcccc}
\hline \multirow{2}{*}{ Drying methods } & \multicolumn{3}{c}{ Storage methods } & Average \\
\cline { 2 - 4 } & $\begin{array}{c}\text { Farmer's } \\
\text { warehouse }\end{array}$ & $\begin{array}{c}\text { Air-conditioned } \\
\text { room }\end{array}$ & $\begin{array}{c}\text { Room } \\
\text { temperature }\end{array}$ & $27.81 \mathrm{a}$ \\
\hline On the field & 26.00 & 31.96 & 25.49 & $29.79 \mathrm{a}$ \\
On woven bamboo nets covered with plastic & 25.62 & 38.30 & 25.45 & $29.75 \mathrm{a}$ \\
On woven bamboo nets uncovered with plastic & 25.87 & 36.33 & 27.05 & 29.12 \\
\hline Average & $25.83 \mathrm{q}$ & $35.53 \mathrm{p}$ & $26.00 \mathrm{q}$ & \\
\hline C.V $(\%)$ & 12.54 & & & \\
\hline
\end{tabular}

Note: The means in one column followed by the same letter were not significantly different according to DMRT ( $\alpha$ 5\%); (-): There is no interaction between factors being tested

of sprouting was due to the increasing of enzyme and gibberellin activities in the cell. Such condition improves the cell division process and the dormancy breakage resulting in the changes of appearance that triggered the formation of roots and shoots.

Based on the variance analysis results (Table 6), the drying and storage method did not give significant effect to the number of damaged bulbs. This indicated that during the storage, all treatments still experienced disease attack that caused bulbs damage. However, the damaged bulbs percentage was categorized low and it ranged from 3.24 to 5.72. This was expected due to the low humidity effect which was between 54 and $71 \%$ that suppressed the microbial growth.
According to Komar (2001), high humidity can stimulate the decay process, especially when there is a change or variation of indoor temperature. Further, it was explained that when $100 \%$ relative humidity was reached, it would also give impact to the occurrence of water condensation and consequently, it resulted in more difficult fungus control.

Germination percentage is one of the parameters of seed viability. There was no interaction between drying and storage methods to the germination percentage, vigor index, as well as germination speed (Table 7 and Table 8). All drying and storage treatments resulted in similar germination percentage $(100 \%)$ indicating fine germination percentage for 
all treatments with no inhibited seed germination. According to Soedomo (2006), high germination percentage was positively correlated to high quality of bulbs.

One of high vigor indicators is shown by the ability of the plant to grow (germination percentage) more than $80 \%$ (Sutopo, 2004). The high number of vigor index indicated the seed ability to germinate simultaneously. As presented on Table 7, the drying methods did not significantly affect the vigor index, but the storage methods did. Bulbs stored in the airconditioned room resulted in highest vigor index and differed significantly among other treatments, while the effect of bulbs storage in warehouse and at room temperature resulted in the lowest vigor index. High vigor index obtained by storage treatment in the airconditioned room was followed by high germination speed (Table 8). This was in line with Yudono (2012) that one of the primary characteristics of vigor seed is high speed germination. The high vigor index and growth rate were found in the treatment of bulbs stored in the air-conditioned room because the bulbs stored in such condition are faster to shoot out making them grow faster simultaneously; one of the factors that affect the vigor index is seed dormancy.

As seen on Table 8, bulbs stored in the airconditioned room grew faster and were significantly different from other treatments. The effect of bulbs storage in the farmer's warehouse and at room temperature was the lowest germination speed. The faster the bulbs germinated, the better the quality of the plants would be (Marthen et al., 2013).

\section{CONCLUSIONS}

There were changes occurred during drying and storage experiment based on the quality of shallot bulbs within 12 weeks. However, when ready to be planted after storage period, germination rate and vigor index of the bulbs could still be maintained.

\section{REFERENCES}

AOAC. Association of Official Analysis Chemists. 1995. Official Methods of $16^{\text {th }}$ ed., 45:5-6.

Asgar, A. dan L. Marpaung. 1998. Pengaruh umur panen dan lama penyimpanan terhadap kualitas umur kentang goreng. J. Hortikultura., 8: 12081216.

Asgar, A. dan R.M Sinaga. 1992. Pengeringan bawang merah (Allium ascalonicum L.) dengan menggunakan ruangan berpembangkit Vorteks. J. Hort., 12:48-55.
Astuti, S. M. 2008. Teknik pengeringan bawang merah dengan cara perlakuan suhu dan tekanan vakum. Buletin Teknik Pertanian., 13: 79-82.

Djali, M. dan R. Rachnat. 2013. Perubahan karakteristik umbi bawang merah (Allium ascalonicum $\mathrm{L}$ ) akibat proses curing selama penyimpanan. $J$. Pascapanen., 10: 48-57.

Heatherbell, D.A., M.S. Reid and R.E. Wrolstad. 1982. The amarillo: Chemical composition during growth and maturation. New Zealand J.Sci., 25:239-243.

Hall, C.W. 1980. Drying and storage of sgricultural Crops. The AVI Publishing Inc, Westport, Connecticut, U.S.A., 291-308.

Hervelly. 2005. Pengaruh cara curing konvensional yang dimodifikasi dengan pemberian kecepatan aliran udara yang berbeda terhadap karakteristik umbi bawang merah (Allium ascalonicum L. cv. Bima). Jurnal Infomatek., 7: 233-254.

Komar, N., S. Rakhmadiono dan L. Kurnia. 2001. Teknik penyimpanan bawang merah pasca panen di JawaTimur. Jurnal Teknologi Pertanian., 2: 79-95.

Maemunah. 2010. Viabilitas dan vigor benih bawang merah pada beberapa varietas setelah penyimpanan. J. Agroland., 17: 18-22.

Mardiana, Purwanto, Y.A. dan L. Pujantoro. 2016. Pengaruh penyimpanan suhu rendah benih bawang merah (Allium ascalonicum L.) terhadap pertumbuhan benih. Jurnal Keteknikan Pertanian., 4:6-74.

Marthen, E., Kaya dan H. Rehatta. 2013. Pengaruh perlakuan pencelupan dan perendaman terhadap perkecambahan benih sengon (Paraserianthes falcataria L.). Jurnal Ilmu Budidaya Tanaman., 2: $10-16$.

Maya, S.P. 2012. Pematahan dormansi umbi tiga varietas bawang merah (Allium cepa L. kelompok agregatum) dengan perlakuan suhu. Skripsi. Universitas Gadjah Mada.

Mitra, J., S.L. Shrivastava and P.S. Rao. 2011. Onion dehydration: A review. $J$ Food Sci Technol., 49:267-277.

Musaddad, D. dan R.M. Sinaga. 1995. Pengaruh suhu penyimpanan terhadap mutu bawang merah (Allium ascalonicum L). Bul. Penel. Hort., 26:13-141.

Mutia, A.K. 2014. Penyimpanan bawang merah (Allium ascalonicum L.) pada suhu rendah dan tingkat kadar air Awal yang berbeda. $J$. Pascapanen., 1: 6-13.

Nega, G., A. Mohammed and T. Menamo. 2015. Effect of curing and top removal time on quality and shelf life of onions (Allium cepa L.). 
Global Journal of Science Frontier Research: D Agriculture and Veterinary., 15:1-11.

Nugraha, S., R.S Adrian dan Yulianingsih. 2009. Inovasi teknologi instore drying untuk mempertahankan mutu dan nilai tambah bawang merah. Prosiding Seminar Nasional Mekanisasi Pertanian, Balai Besar Mekanisasi Pertanian, Bogor., 195-206.

Pangidoan, S., Sutrisno dan Y.A. Purwanto. 2014. Transportasi dan simulasinya dengan pengemasan curah untuk cabai keriting segar. Jurnal Keteknikan Pertanian., 28:23-30.

Pantastico, ERB. 1993. Fisiologi Pasca Panen, Penanganandan Pemanfaatan Buah-buahan dan Sayuran Tropika dan Subtropika. Terjemahan Kamariyani. Yogyakarta: UGM Press.

Priyantono, E., A. Ete dan Adrianton. 2013. Vigor umbi bawang merah (Allium Ascallonicum L.) varietas palasa dan lembah palu pada berbagai kondisi simpan. E-J. Agrotekbis., 1: 8-16.

Purwanti, S. 2004. Kajian suhu ruang simpan terhadap kualitas benih kedelai hitam dan kedelai kuning. Ilmu Pertanian., 11: 22-31.
Purwanto, Y.A., S. Oshita., Y. Makino dan Y. Kawagoe. 2012. Indikasi kerusakan dingin pada mentimun Jepang (Cucumis Sativus L.) berdasarkan Perubahan ion leakage dan pH. Jurnal Keteknikan Pertanian., 26: 33-37.

Wills, R.H., T.H. Lee., D. Graham., Mc. Gkasson and W.B. Hall. 1981. Postharvest, An introduction to the physiology and handling of fruits and vegetables. Australia: New South Wales University Press, Kensington.

Raka, I. G. N., A.A.M. Astiningsih., I. D. N. Nyana dan I.K. Siadi. 2012. Pengaruh dry heat treatment terhadap daya simpan benih cabai rawit (Capsicum frutescens L.). J. AgricSci and Biotechnol., 1: 01-11.

Sinaga, R.M. dan Nurhartuti. 1992. Pengaruh cara penyimpanan terhadap mutu bawang merah (Allium ascalonicum L.). Bul. Penel. Hort., 20:143-150.

Sutopo, L. 2004. Teknologi benih. Jakarta: Penerbit Rajawali.

Tucker, G.A. 1993. Biochemistry of fruit ripening. London: Chapman and Hall.

Yudono, P. 2012. Perbenihan tanaman. Dasar Ilmu, Teknologi dan Pengelolaan. Yogyakarta: Gadjah Mada University Press. 